\title{
VITAMIN A AND CAROTENE STUDIES WITH FATTENING BEEF CATTLE ${ }^{1}$
}

\author{
W. K. Roberts and G. D. Phillips \\ University of Manitoba, Winnipeg, Manitoba
}

[Received for publication October 1, 1962]

\begin{abstract}
Three feeding trials were conducted to study the effect of feeding various levels of vitamin A or carotene on weight gains, feed conversion and changes in liver vitamin A stores of fattening steers. The daily intake of 6,000 I.U. of vitamin A did not prevent vitamin A deficiency during a 126-day feeding period, when average initial liver vitamin A stores of the steers were 6.8 micrograms per gram of fresh liver. On the other hand, steers with liver vitamin A stores of 51.8 micrograms per gram of fresh liver, and receiving no supplemental vitamin A or carotene, showed no vitamin A deficiency symptoms and gained approximately the same as steers receiving 17,958 or 35,875 I.U. of vitamin A daily during a 133 -day feeding period. Steers receiving the vitamin A-carotene free rations did not require significantly more feed per 100 pounds gain than steers receiving similar rations and supplemented with various levels of vitamin A or carotene. Initial liver vitamin A stores of 73.4 micrograms per gram of fresh liver were not maintained in fattening steers receiving 72,100 I.U. of vitamin A daily during 112 days. Steers consuming 63.3 milligrams of B-carotene or 25,000 I.U. of vitamin A daily showed similar losses in initial liver vitamin A stores during 133 days, suggesting a conversion ratio of carotene to vitamin A of approximately 8.4:1, on a weight basis.
\end{abstract}

\section{INTRODUCTION}

There is considerable controversy as to the quantity of vitamin A required for optimal feed lot performance of fattening steers. The N.R.C. (8) recommends approximately 6,800 I.U. of vitamin A daily for fattening yearling steers. However, Perry et al. (10) reported that 20,000 I.U. of vitamin A daily were required for maximum daily gains of steer calves and Meyer (7) recommended 3,000 I.U. of vitamin A daily per 100 pounds of body weight for fattening beef cattle.

Carotene is an important source of vitamin $\mathrm{A}$ and, depending upon feeding practices, may supply a part or all of the vitamin A in cattle-fattening rations. However, the efficiency of conversion of carotene to vitamin A in cattle has not been clearly defined. Guilbert et al. (5) reported that the daily minimum carotene or vitamin A requirement of mature beef cows was 26-33 or 5.1-6.4 micrograms/kilogram of body weight, respectively, thus indicating a conversion ratio, on a weight basis, of approximately $5: 1$. Rousseau et al. (11) determined the quantities of vitamin A or carotene which were required to maintain specific plasma and liver vitamin A levels in vitamin A-depleted Holstein calves. From their data conversion ratios of approximately $8.2: 1$ or $10: 1$, on a weight basis, can be calculated. In assessing the vitamin A value of carotene for cattle, the N.R.C. (8) used a carotene to vitamin A conversion ratio of $8.33: 1$, on a weight basis.

Since a dietary source of vitamin A is important for beef cattle it seemed desirable to further investigate certain facets of vitamin A and carotene requirements in relation to the nutrition of fattening beef steers. This report presents the results of three feeding trials in which body weight gains, feed conversion and liver vitamin A stores were criteria used to ascertain the efficiency of conversion of carotene to vitamin A and the dietary requirement for vitamin $\mathrm{A}$.

\footnotetext{
${ }^{1}$ Contribution from the Department of Animal Science, University of Manitoba, Winnipeg, Man.
} 


\section{MATERIALS AND METHODS}

Yearling Hereford steers were used in three different feeding trials. The basal ration fed to all animals contained minimum amounts of carotene. It consisted of 2 pounds of wheat or oat straw daily per head, plus a mixture of dry rolled grains containing 75 per cent barley and 25 per cent oats by weight. Bonemeal, limestone and salt were fed in quantities to supply at least the N.R.C. recommended levels (8) of calcium, phosphorus and sodium. Depending upon objectives of the experiment commercial forms of either vitamin A palmitate or synthetic B-carotene were fed*. All animals were implanted with 36 milligrams of stilbestrol at initiation of the feeding trials. Wood shavings were used for bedding.

Liver samples were taken during the early part of each feeding trial, using the liver biopsy technique described by Erwin et al. (3). A final liver sample was taken from each animal at slaughter from the area in the liver where the previous biopsy had been made. The vitamin A content in the liver samples was estimated according to the method of Gallup and Hoefer (4). Approximately midway through each experiment a sample of straw was analysed for carotene content by the approved A.O.A.C. procedure (1). In addition, the straw used in Trials II and III was analysed for nitrate content by an adaptation of Devarda's method (A.O.A.C.).

When a majority of the steers had attained market weight each experiment was terminated and the animals slaughtered.

Statistical analyses of the data were conducted by analysis of variance and, where applicable, treatment means were compared using the method described by Duncan (2).

\section{Trial I}

This feeding trial was conducted over a 126-day period, beginning in the middle of April. Twenty-four steers which had previously been depleted of a majority of their liver vitamin A stores were randomly allotted to four groups of six animals each. The animals were stanchioned twice daily and individually fed as much of the grain mixture as they could clean up during a period of approximately 1 hour each morning and evening. Two levels of vitamin A (6,000 and 14,000 I.U.) and 2 levels of B-carotene (15 and 35 milligrams) were fed daily to each animal (Table 1). The two levels of carotene were calculated to supply 6,000 and 14,000 I.U. of vitamin A equivalent daily, using the N.R.C. (8) recommendation that 1 milligram of carotene equals 400 I.U. of vitamin A. The vitamin A or carotene was pre-mixed with the minerals and a weighed quantity added to the grain mix at the morning feeding. The vitamin $\mathrm{A}$ and carotene pre-mixes were prepared every 2 weeks. The animals were weighed at weekly intervals throughout the 126-day experimental period. Liver samples were taken at the beginning and end of the experiment $(0$ and 126 days).

\footnotetext{
* Appreciation is expressed to Pfizer, Canada, for supplying dry vitamin A palmitate in gelatin, and to Hoffman-La Roche, Ltd., for supplying dry stabilized B-carotene beadlets, which are waterdispersible, and dry vitamin $\mathrm{A}$ palmitate used in these experiments.
} 


\section{Trial II}

The feeding trial was of 133-day duration and initiated during the first part of October. The animals were maintained in an outside environment, with access to a partially enclosed shelter. There was a wide variation in outside temperatures during the experimental period, which ranged from a high of $+85^{\circ} \mathrm{F}$. during the early part of the experiment to a low of $-35^{\circ} \mathrm{F}$. during the latter part of the experiment.

Twenty-four steers of unknown nutritional history were randomly allotted to four groups of six animals each. The vitamin $\mathrm{A}$ and minerals were mixed with the grain and the average daily intakes of vitamin $\mathbf{A}$ for the four groups were: $0 ; 17,958 ; 35,875$ and 72,100 I.U. per head, respectively. The animals were group-fed and, after an adjustment period, the grain-mineral-vitamin A mixture was fed ad libitum. The animals were weighed every 2 weeks and liver samples were obtained 21 days after the start of the experiment and again when the animals were slaughtered.

\section{Trial III}

This feeding trial was initiated in late October and the animals were penned inside a heated barn where ambient temperatures ranged from $+40^{\circ} \mathrm{F}$. to $+60^{\circ} \mathrm{F}$. Twenty-four animals of unknown nutritional history were randomly allotted to six groups of four animals each, and fed the experimental rations for 147 days. The following daily intakes of either vitamin A or carotene were provided: $0,25,000$ I.U. of vitamin A; 63.3, 55.6, 48.1 and 40.6 milligrams, respectively, of B-carotene (Table 3 ). These amounts of carotene would be equivalent to 25,000 I.U. of vitamin A assuming conversion ratios of $8.4,7.4,6.4$ and $5.4: 1$, respectively, on a weight basis.

These animals were individually fed according to the procedure described in Trial I. The animals were weighed at 2 -week intervals and liver samples were taken on the 14th day of the test and at slaughter.

\section{RESULTS}

There were no significant differences among treatments in average daily gains or feed conversion in Trial I (Table 1). Initial liver vitamin A stores of these animals were considered low (group averages were 6.8, 9.8, 6.0 and $12.9 \mu \mathrm{g} . / \mathrm{g}$. fresh liver) and, regardless of treatment, the quantitative changes in stores during the experimental period were relatively small. No significant treatment differences in expenditure of liver vitamin A stores were observed during the 126-day period. Two weeks after this experiment started one animal died in the group receiving 6,000 I.U. of vitamin A. The autopsy indicated that "over-eating disease" was the cause of death. Symptoms suggesting vitamin A deficiency were observed in two steers receiving 6,000 I.U. of vitamin A. One animal, after about 100 days on test, showed tetany when excited, and the second was blind after 114 days.

Carotene could not be detected in the wheat straw used in this trial.

In Trial II there was considerable variation among groups in average initial liver vitamin A stores (Table 2). During the last 112 days of the experiment liver vitamin A stores decreased in all groups. The differences among groups in liver vitamin A decrease were not significant. Liver 
Table 1. - Trial 1. Average initial and final steer weights, Dally gain, FeEd PER 100 LB. GAIN, INITIAL AND FINAL LIVER VITAMIN A STORES, DECREASE IN LIVER VITAMIN A STORES AND THE PER CENT OF LIVER VITAMIN A STORES EXPENDED IN FATTENING STEERS DURING A 126-DAY EXPERIMENTAL PERIOD

\begin{tabular}{|c|c|c|c|c|}
\hline \multirow[t]{2}{*}{. } & \multicolumn{4}{|c|}{ Treatment } \\
\hline & $\begin{array}{l}6,000 \mathrm{I} . \mathrm{U} \\
(2.06 \mathrm{mg} .)^{2} \\
\text { vitamin A } \\
\text { daily }\end{array}$ & $\begin{array}{l}14,000 \text { I.U. } \\
(4.82 \mathrm{mg.}) \\
\text { vitamin A } \\
\text { daily }\end{array}$ & $\begin{array}{l}15 \mathrm{mg} . \\
\text { carotene } \\
\text { daily }\end{array}$ & $\begin{array}{l}35 \mathrm{mg} . \\
\text { carotene } \\
\text { daily }\end{array}$ \\
\hline $\begin{array}{l}\text { Number of steers } \\
\text { Average initial weight (lb.) } \\
\text { Average final weight (lb.) } \\
\text { Average daily gain (lb.) }\end{array}$ & $\begin{array}{c}5 \\
731 \\
1055 \\
2.57 \\
( \pm 0.18)^{1}\end{array}$ & $\begin{array}{r}6 \\
701 \\
1025 \\
2.57 \\
( \pm 0.14)\end{array}$ & $\begin{array}{r}6 \\
696 \\
1026 \\
2.62 \\
( \pm 0.13)\end{array}$ & $\begin{array}{r}\quad 6 \\
725 \\
1074 \\
2.77 \\
( \pm 0.15)\end{array}$ \\
\hline $\begin{array}{l}\text { Average feed per } 100 \\
\text { pounds gain (lb.) }\end{array}$ & $\begin{array}{l}729 \\
( \pm 73)\end{array}$ & $\begin{array}{l}737 \\
( \pm 25)\end{array}$ & $\begin{array}{c}688 \\
( \pm 25)\end{array}$ & $\begin{array}{c}695 \\
( \pm 36)\end{array}$ \\
\hline $\begin{array}{l}\text { Average initial liver } \\
\text { vitamin A stores } \\
(\mu \mathrm{g} . / \mathrm{g} . \text { fresh liver })\end{array}$ & $\begin{array}{c}6.8 \\
( \pm 0.8)\end{array}$ & $\begin{array}{r}9.8 \\
( \pm 1.3)\end{array}$ & $\begin{array}{c}6.0 \\
( \pm 1.1)\end{array}$ & $\begin{array}{c}12.9 \\
( \pm 3.3)\end{array}$ \\
\hline $\begin{array}{l}\text { Average final liver } \\
\text { vitamin A stores } \\
(\mu \mathrm{g} . / \mathrm{g} . \text { fresh liver })\end{array}$ & $\begin{array}{c}0.7 \\
( \pm 0.2)\end{array}$ & $\begin{aligned} & 0.8 \\
&( \pm 0.3)\end{aligned}$ & $\begin{array}{c}0.6 \\
( \pm 0.2)\end{array}$ & $\begin{aligned} & 4.6 \\
&( \pm 2.3)\end{aligned}$ \\
\hline $\begin{array}{l}\text { Average decrease in liver } \\
\text { vitamin A stores } \\
(\mu \mathrm{g} . / \mathrm{g} . \text { fresh liver })\end{array}$ & $\begin{array}{c}6.1 \\
( \pm 0.9)\end{array}$ & $\begin{array}{r}9.0 \\
( \pm 1.5)\end{array}$ & $\begin{aligned} & 5.4 \\
&( \pm 1.2)\end{aligned}$ & $\begin{array}{c}8.3 \\
( \pm 1.6)\end{array}$ \\
\hline $\begin{array}{l}\text { Per cent liver vitamin A } \\
\text { stores expended }\end{array}$ & 89.7 & 91.8 & 90.0 & 64.3 \\
\hline
\end{tabular}

'Standard error

2The daily supplemental vitamin A expressed on a mass basis as vitamin A acetate

vitamin A losses may also be expressed as a per cent of the initial liver vitamin A stores [Page et al. (9)]. Such calculations indicated that the steers receiving no vitamin A lost a greater proportion of their initial stores than animals receiving the other rations and compared with the animals receiving 72,100 I.U. of vitamin A daily the difference was considerable (Table 2).

In Trial II, differences among treatments in average daily gains were not significant. Average daily gains of steers receiving 0; 17,958 and 35,875 I.U. of vitamin A daily were similar and were superior to gains of animals receiving 72,000 I.U. of vitamin A daily (Table 2 ). No symptoms indicative of vitamin A deficiency were observed during the 133-day experimental period.

The straw fed in this trial supplied approximately 0.6 milligram daily of carotene and contained 0.12 per cent potassium nitrate.

In Trial III, there was considerable variation among treatments in average daily gain and feed conversion (Table 3 ). Steers receiving the ration containing no supplemental vitamin $\mathrm{A}$ or carotene and the ration supplying 25,000 I.U. of vitamin A daily gained significantly $(P<0.01)$ slower than animals receiving 63.3 milligrams of carotene. Feed required 


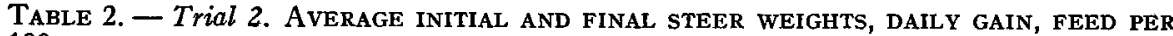
100 LB. GAIN, INITIAL AND FINAL LIVER VITAMIN A STORES, DECREASE IN LIVER VITAMIN A STORES AND THE PER CENT OF LIVER VITAMIN A STORES EXPENDED IN FATTENING STEERS

\begin{tabular}{|c|c|c|c|c|}
\hline & \multicolumn{4}{|c|}{ Treatment } \\
\hline & $\underset{A}{\text { No vitamin }}$ & $\begin{array}{l}17,958 \text { I.U. } \\
(6.18 \mathrm{mg} .)^{3} \\
\text { vitamin A } \\
\text { daily }\end{array}$ & $\begin{array}{l}35,875 \text { I.U. } \\
(12.34 \text { mg. }) \\
\text { vitamin A } \\
\text { daily }\end{array}$ & $\begin{array}{l}72,100 \mathrm{I} . \mathrm{U} \\
(24.80 \mathrm{mg} .) \\
\text { vitamin } \mathrm{A} \\
\quad \text { daily }\end{array}$ \\
\hline $\begin{array}{l}\text { Number of steers } \\
\text { Average initial weight (lb.) } \\
\text { Average final weight (lb.) } \\
\text { Average daily gain during } 133 \\
\text { day period (lb.) }\end{array}$ & $\begin{array}{l}6 \\
682 \\
1074 \\
2.95 \\
( \pm 0.08)^{2}\end{array}$ & $\begin{array}{r}6 \\
655 \\
1052 \\
2.98 \\
( \pm 0.14)\end{array}$ & $\begin{array}{c}6 \\
687 \\
1095 \\
3.07 \\
( \pm 0.15)\end{array}$ & $\begin{array}{c}6 \\
712 \\
1061 \\
2.62 \\
( \pm 0.12)\end{array}$ \\
\hline $\begin{array}{l}\text { Average feed per } 100 \text { pounds } \\
\text { gain (lb.) }\end{array}$ & 775 & 754 & 732 & 861 \\
\hline $\begin{array}{l}\text { Average initial liver vitamin A } \\
\text { stores }^{1}(\mu \mathrm{g} . / \mathrm{g} \text {. fresh liver })\end{array}$ & $\begin{array}{c}51.8 \\
( \pm 8.0)\end{array}$ & $\begin{array}{c}60.5 \\
( \pm 9.9)\end{array}$ & $\begin{array}{c}60.6 \\
( \pm 10.5)\end{array}$ & $\begin{array}{c}73.4 \\
( \pm 6.6)\end{array}$ \\
\hline $\begin{array}{l}\text { Average final liver vitamin A } \\
\text { stores }(\boldsymbol{\mu g} . / \mathrm{g} \text {. fresh liver })\end{array}$ & $\begin{array}{c}6.5 \\
( \pm 2.0)\end{array}$ & $\begin{array}{c}17.0 \\
( \pm 5.7)\end{array}$ & $\begin{array}{c}21.7 \\
( \pm 6.8)\end{array}$ & $\begin{array}{c}40.0 \\
( \pm 9.1)\end{array}$ \\
\hline $\begin{array}{l}\text { Average decrease in liver } \\
\text { vitamin A stores ( } \mu \mathrm{g} . / \mathrm{g} \text {. } \\
\text { fresh liver) }\end{array}$ & $\begin{array}{c}45.3 \\
( \pm 7.4)\end{array}$ & $\begin{array}{c}43.5 \\
( \pm 5.7)\end{array}$ & $\begin{array}{c}38.9 \\
( \pm 5.1)\end{array}$ & $\begin{array}{c}33.4 \\
( \pm 5.4)\end{array}$ \\
\hline $\begin{array}{l}\text { Per cent liver vitamin A stores } \\
\text { expended during } 112 \text { days }\end{array}$ & 87.5 & 71.9 & 64.2 & 45.5 \\
\hline
\end{tabular}

'Liver samples were taken 21 days after the start of the trial for the values presented. 'Standard error

The daily supplemental vitamin A expressed on a mass basis as vitamin A acetate

per 100 pounds gain for animals receiving 63.3 or 48.1 milligrams of carotene was significantly less $(P<0.05)$ than animals receiving 25,000 I.U. of vitamin A. Again, as in the first two trials, liver vitamin A stores decreased in all animals; but there were no significant differences, in actual losses, due to treatment. However, when the losses were expressed as percentages of the initial liver levels of vitamin A, marked treatment differences were observed (Table 3). Animals receiving 63.3 milligrams of carotene or 25,000 I.U. of vitamin A daily lost approximately the same proportion of their initial stores (56.0 and 58.9 per cent, respectively) while steers receiving no supplemental vitamin A or carotene lost considerably more (95.7 per cent). Except for a reduction in daily weight gains, animals receiving the vitamin A-free ration did not exhibit vitamin A deficiency symptoms. One animal in the group receiving 55.6 milligrams of carotene daily developed anorexia and showed a rapid loss in body weight. This animal was taken off test and marketed.

The quantity of carotene supplied by straw in Trial III was approximately 0.8 milligram daily per head, and the straw contained 0.11 per cent potassium nitrate. 


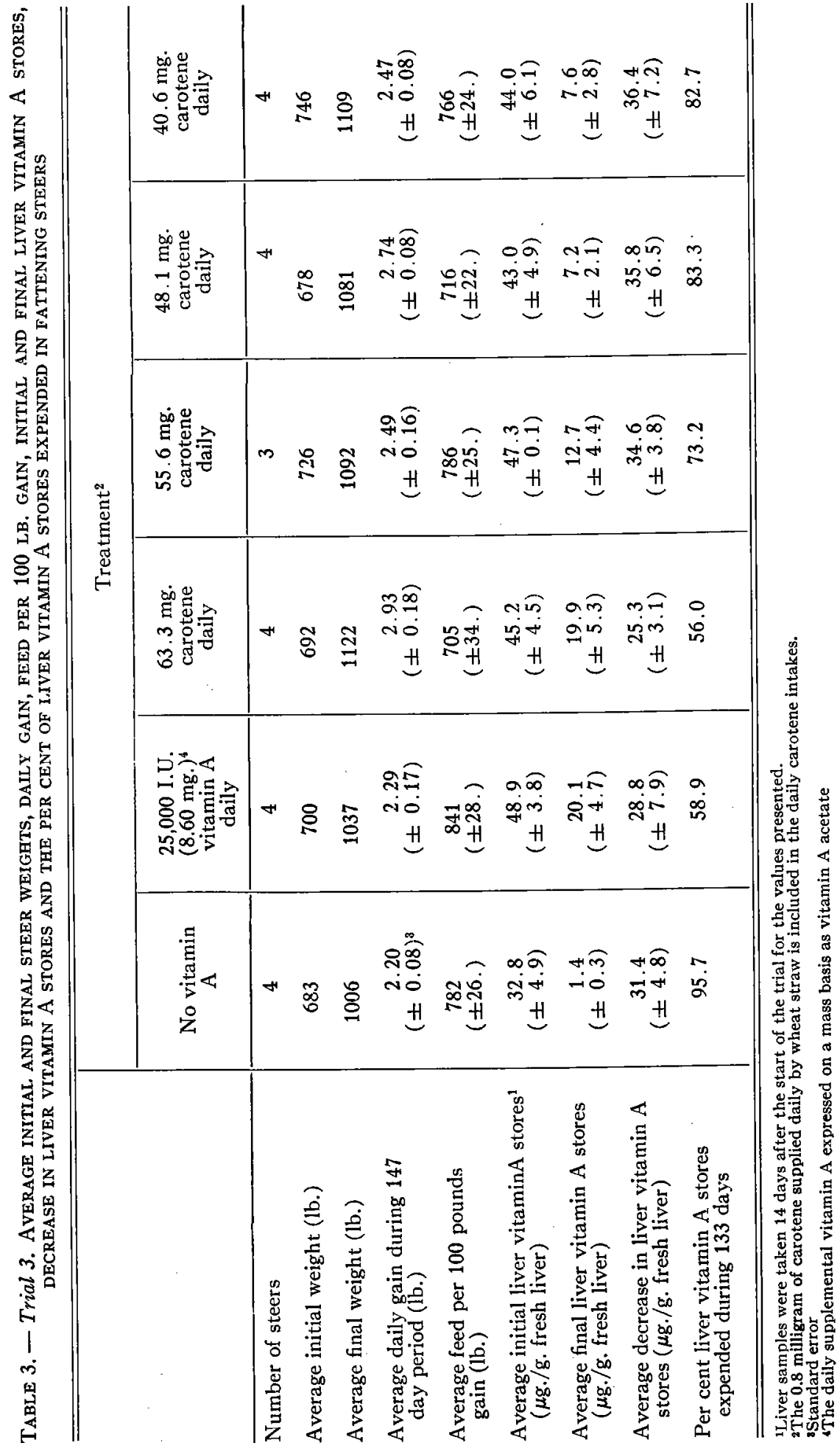


The average weight gains of animals receiving carotene in Trials I and III were greater in all cases than those of animals receiving vitamin A. In fact, the steers in Trial III receiving 63.3 milligrams of carotene gained significantly $(P<0.01)$ faster than steers receiving 25,000 I.U. of vitamin $A$ daily (Table 3). The animals receiving 25,000 I.U. of vitamin A in Trial III gained relatively poorly and had poor feed conversion. No explanation is offered for the sub-optimal performance of these animals.

\section{DISCUSSION}

The growth and feed conversion data from Trials I and III are somewhat equivocal from the standpoint of determining the conversion of carotene to vitamin A. However, with regard to this conversion a comparison might be made between animals in Trial III which were receiving $63.1 \mathrm{milli}$ grams of carotene and 25,000 I.U. of vitamin A daily. Animals in both groups lost a similar per cent of their liver vitamin A stores during a 133-day period. Using this as the criterion for estimating the conversion ratio of carotene to vitamin $\mathrm{A}$, a value of approximately $8.4: 1$, on a weight basis, was calculated, which is similar to that used by the N.R.C. (8).

Results from Trials II and III indicate that, when an essentially vitamin A-free ration is fed, the time required for impairment of average daily gains to occur is dependent upon initial body vitamin A stores. In one case (Trial II) 133 days was not long enough for a depression in gains to become apparent when liver vitamin A stores at the 21 st day of the experiment averaged 51.8 micrograms vitamin A per gram of fresh liver. On the other hand, poor gains were observed in animals (Trial III) receiving a similar vitamin A-free ration over a 147-day period, but initial liver vitamin A stores were lower (32.8 micrograms vitamin A per gram of fresh liver after 14 days on test).

The daily vitamin A requirements of fattening steers recommended by Perry et al. (10) and Meyer (7) are not necessarily corroborated by the present studies. The present data suggest that the minimum dietary vitamin A requirements for optimal weight gains of fattening steers depend on liver vitamin A stores. As previously mentioned, consumption of a vitamin Afree, very low carotene ration had essentially no adverse effect on weight gains or feed conversion during a 133-day fattening period, when initial liver vitamin A stores were relatively high. On the other hand, when initial liver vitamin A stores were low, gains were poorer when low levels of vitamin $\mathrm{A}$ or carotene were fed. These data suggest that the N.R.C. (8) recommendation of approximately 6,800 I.U. of vitamin A daily is adequate for satisfactory weight gains if sufficient vitamin $A$ is present in the liver. However, as indicated in Trial I, if liver vitamin A levels are low ( $6.8 \mu \mathrm{g} . / \mathrm{g}$. fresh liver) at the beginning of a lengthy feeding period, then the N.R.C. (8) requirements may be too low to prevent the appearance of vitamin A deficiency and consequently sub-optimum weight gains.

The discrepancies existing in the literature regarding suggested vitamin A requirements of fattening beef steers are points for conjecture. One important reason could be that steers, used by different research workers to establish the vitamin A requirement, had greatly differing vitamin A stores 
at the initial part of the experimental period. If this was the case, then steers with high liver vitamin A stores would need relatively little dietary vitamin A during the experimental period. Conversely, steers with low initial vitamin A stores would show a much higher dietary requirement during approximately the same period. This strongly suggests that liver vitamin A stores of animals at the initial part of a test should be taken into consideration when experiments are conducted for the purpose of determining the vitamin A requirement of fattening steers.

The quantity of dietary vitamin A required to maintain liver vitamin A levels is of interest. Hale et al. (6) reported that $40,000 \mathrm{I} . \mathrm{U}$. of vitamin A daily would maintain initial liver vitamin A levels ( $98 \mu \mathrm{g} . / \mathrm{g}$. fresh liver) in fattening steers over 168 days. In the present study, higher vitamin A consumption (72,100 I.U. vitamin A daily) did not maintain lower liver vitamin A levels $(73.3 \mu \mathrm{g} . / \mathrm{g}$. fresh liver) during 112 days. Animals in the present study were gaining quite rapidly (average of 2.62 pounds daily), which may partially explain the apparently divergent results.

\section{REFERENCES}

1. Association of Official Agricultural Chemists. 1960. Official method of analysis. 9th ed. Washington, D.C.

2. Duncan, D. B. 1955. Multiple range and multiple F-tests. Biometrics 11:1-42.

3. Erwin, E. S., I. A. Dyer, T. O. Meyer, and K. W. Scott. 1956. Uses of aspiration biopsy technique. J. Animal Sci. 15:428-434.

4. Gallup, W. D., and J. A. Hoefer. 1946. Determination of vitamin A in the liver. Ind. Eng. Chem. Anal. Ed. 18:288-290.

5. Guilbert, H. R., C. E. Howell, and G. H. Hart. 1940. Minimum vitamin A and carotene requirements of mammalian species. J. Nutrition 19:91-103.

6. Hale, W. H., Farris Hubbert, Jr., R. E. Taylor, T. A. Anderson, and B. Taylor. 1962. Performance and tissue vitamin A levels in steers fed high levels of vitamin A. Amer. J. Vet. Research 23:992-996.

7. Meyer, W. H. 1961. Vitamin A nutrition of beef cattle. Feedstuffs 33, No. 30:1 and 78.

8. National Research Council. 1958. Nutrient requirements of domestic animals; No. 4. Nutrient requirements of beef cattle, Publ. 579. Washington, D.C.

9. Page, H. M., E. S. Erwin, T. R. Varnell, and C. B. Roubicek. 1958. Effect of hepatic vitamin $\mathrm{A}$ and carotene concentration on the biological value of carotene in the bovine. Amer. J. Physiol. 194:313-315.

10. Perry, T. W., W. M. Beeson, M. T. Mohler, and W. H. Smith. 1962. Levels of supplemental vitamin $A$ with and without sun-cured alfalfa meal for fattening steer calves. J. Animal Sci. 21:333-339.

11. Rousseau, J. E., Jr., H. D. Eaton, C. F. Helmboldt, E. L. Jungherr, S. A. Robrish, G. Beall, and L. A. Moore. 1954. Relative value of carotene from alfalfa and vitamin A from a dry carrier fed at minimum levels to Holstein calves. J. Dairy Sci. 37:889-899. 